\title{
Effect of thalidomide in patients with $\beta$-thalassemia major
}

\begin{abstract}
Introduction: Thalassemia is among the common hereditary disease, caused by synthesis of defective haemoglobin, leading to ineffective erythropoiesis, chronic haemolytic anaemia and certain clinical complications. Various treatment options are available for treatment of $\beta$-thalassemia major including regular blood transfusion, iron chelation therapy and hydroxyurea. Although complications and poor survival is still major problem in these patients. So treatment with alternative drugs can be helpful in management of these patients.
\end{abstract}

Methods and materials: Prospective study, conducted at a tertiary care hospital. Study included 70 known cases of transfusion dependant thalassemia major. Age, gender, haemoglobin and serum ferritin levels were analyzed before and after treatment with thalidomide. All data were collected and analyzed in SPSS 21.0. P-value of $<0.05$ was considered as statistically significant.

Results: Among 70 patients, 46 were males and 24 were females (male to female ratio=1.9:1). Mean age of the patients was $10.31 \pm 1.24$ years. Before and after treatment with thalidomide, mean haemoglobin was $8.93 \pm 1.04 \mathrm{~g} / \mathrm{dL}$ and $10.54 \pm 1.18 \mathrm{~g} /$ $\mathrm{dL}$ respectively $(\mathrm{p}=0.011)$. Before and after treatment, mean serum ferritin level was $3125 \pm 143.51 \mathrm{ng} / \mathrm{mL}$ and $1241 \pm 135.94 \mathrm{ng} / \mathrm{mL}(\mathrm{p}>0.001)$.

Conclusion: Thalidomide proved to increased haemoglobin levels and reducing ferritin levels in patients with $\beta$-thalassemia major.

Keywords: $\beta$-thalassemia, thalidomide, haemoglobin, ferritin
Volume 6 Issue 6 - 2018

\author{
Shahzad Ali Jiskani,' Sumair Memon² \\ 'Department of Pathology, Indus Medical College Tando \\ Muhammad Khan, Pakistan \\ ${ }^{2}$ Department of Pathology, Liaquat Univesity of Medical and \\ Health Sciences Jamshoro, Pakistan
}

\section{Correspondence: Shahzad Ali Jiskani, Shaheed Zulfiqar Ali Bhutto Medical University/ Pakistan Institute of Medical Sciences Islamabad, House No. 482, Behrani Muhallah, Tando Muhammad Khan, Pakistan, Tel 3332672268. \\ Email shahzabbaloach289@gmail.com}

Received: September 29, 2018 | Published: November 21, 2018

\section{Introduction}

Thalassemia is a group of autosomal recessive inherited blood disorder characterized by reduced or no production of $\beta$-globin gene, ultimately leading to reduction in haemoglobin levels, reduced synthesis of erythrocytes and anaemia. $\beta$-thalassemia is a group of hereditary blood disorder in which there is reduced or no production of $\beta$ globin genes occurs, leading to decrease production of haemoglobin. ${ }^{1}$ It was originated and spread over Middle East, Mediterranean and Southeast Asia. ${ }^{2}$

There are several treatment options for patients with $\beta$-thalassemia major but due to poor availability of medical care, safe and adequate transfusion of red blood cells, high cost and poor compliance with chelation therapy remains a challenging situation in developing countries. Treatment of $\beta$-thalassemia major is not considered easy due to severe complications in these patients including pericarditis, hypercoagulability, iron overload, hepatocellular carcinoma, osteoporosis and psychological problems. ${ }^{3,4}$ Traditional therapy in patients with $\beta$-thalassemia major includes supportive therapy by transfusion of red blood cells, iron chelation therapy to remove excessive amount of iron in the body, hydroxyurea therapy, erythropoietin etc. ${ }^{5,6}$

Despite of availability of various treatment options in $\beta$ thalassemia major, there are various complications being faced worldwide. Thalidomide was previously used to treat multiple myeloma. It has also significant role on $\mathrm{HbF}$. Exact aetiology of its role is not known but it may be due to suppression of NF-KB induction caused by certain inflammatory cytokines including tumor necrotic factor- $\alpha(\mathrm{TNF}-\alpha)$, prostaglandin E2 synthesis (PG-E2), and vascular endothelial growth factor (VEGF), in association with increase in release of reactive oxygen species (ROS). Reactive oxygen species launches P38 MAPK, which causes increase in HbF levels. ${ }^{7,8}$

We analyzed the effect of thalidomide in patients with $\beta-$ thalassemia major.

\section{Materials and methods}

It was a prospective study conducted at a tertiary care centre. 70 patients were included in this study. All patients were known cases of transfusion dependant $\beta$-thalassemia major. Study was performed from October 2017 to April 2018. Thalidomide was given at a dose of $2 \mathrm{mg} / \mathrm{kg}$ to $10 \mathrm{mg} / \mathrm{kg}$ for $6 \mathrm{months}$. Age, gender, haemoglobin levels, ferritin levels before and after therapy were assessed in all patients. 2 blood samples from each patient were taken. One sample was taken in tube containing EDTA for evaluation of haemoglobin levels. Other sample was taken in tube containing Gel for evaluation of serum ferritin. All data was collected and was analyzed in SPSS 21.0.

\section{Results}

This study included 70 patients, including 46 males and 24 females. Male to female ratio was high (1.9:1) (Figure 1). Age of patients was ranged from 7years to 12years (mean=10.31 1.24 years) (Table 1). Haemoglobin and serum ferritin levels were measured in all patients before and after treatment thalidomide.

Before treatment, haemoglobin was ranged from 7.23 to $9.41 \mathrm{~g} /$ $\mathrm{dL}$ (mean $=8.93 \pm 1.04 \mathrm{~g} / \mathrm{dL}$ ), while after treatment with thalidomide, 
it ranged from 9.83 to 11.21 (mean=10.54 $\pm 1.18 \mathrm{~g} / \mathrm{dL}$ ) (Table $1 \& 2$ )

(Figure 2). There was statistically significant difference $(\mathrm{p}=0.011)$.

\section{Gender Distribution $(n=70)$}

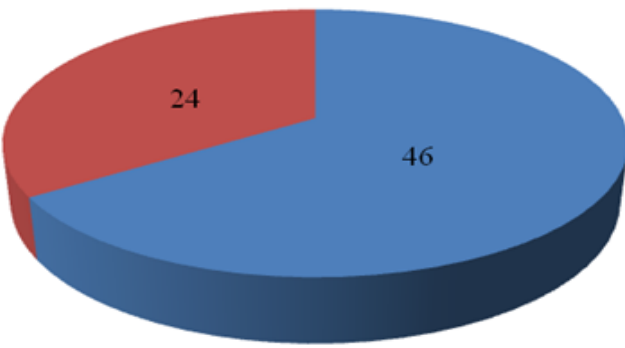

Figure 1 Gender distribution.

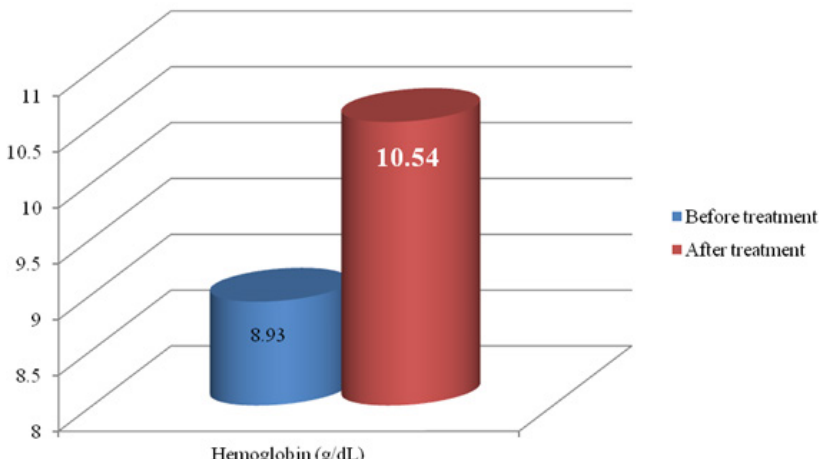

Figure 2 Haemoglobin levels before and after treatment $(\mathrm{n}=70)$.

Table 1 Evaluation of age, haemoglobin and serum ferritin levels before and after treatment $(\mathrm{n}=70)$

\begin{tabular}{llll}
\hline & Mean & $\begin{array}{l}\text { Standard } \\
\text { Deviation }\end{array}$ \\
\hline Age & & 10.31 & 1.24 \\
$\begin{array}{l}\text { Haemoglobin } \\
(\mathrm{g} / \mathrm{dL})\end{array}$ & Before treatment & 8.93 & 1.04 \\
& After treatment & 10.54 & 1.18 \\
$\begin{array}{l}\text { Serum ferritin } \\
(\mathrm{ng} / \mathrm{mL})\end{array}$ & Before treatment & 3125.24 & $143.5 \mathrm{I}$ \\
& After treatment & 1241.85 & 135.94
\end{tabular}

Table 2 Difference in haemoglobin and ferritin levels before and after treatment $(\mathrm{n}=70)$

\begin{tabular}{llll}
\hline & $\begin{array}{l}\text { Before } \\
\text { Treatment }\end{array}$ & $\begin{array}{l}\text { After } \\
\text { Treatment }\end{array}$ & P-value \\
\hline $\begin{array}{l}\text { Mean haemoglobin } \\
(\mathrm{g} / \mathrm{dL})\end{array}$ & $8.93 \pm 1.04$ & $10.54 \pm \mathrm{I} .18$ & $0.01 \mathrm{I}$ \\
$\begin{array}{l}\text { Mean serum ferritin } \\
(\mathrm{ng} / \mathrm{mL})\end{array}$ & $3125.23 \pm 143.5 \mathrm{I}$ & $124 \mathrm{I} \pm 135.94$ & $<0.00 \mathrm{I}$ \\
\hline
\end{tabular}

Before treatment, serum ferritin was 2538 to $6429 \mathrm{ng} / \mathrm{mL}$ (mean $=3125 \pm 143.51 \mathrm{ng} / \mathrm{mL}$ ), while after treatment, it was 873 to $1582 \mathrm{ng} / \mathrm{mL}$ (mean=135.94ng/mL) (Table $2 \& 3$ ) (Figure 3). The difference was statistically significant $(\mathrm{p}<0.001)$. Clinical features of patients are described (Table 3). All patients showed different transfusion frequencies (Table 4).

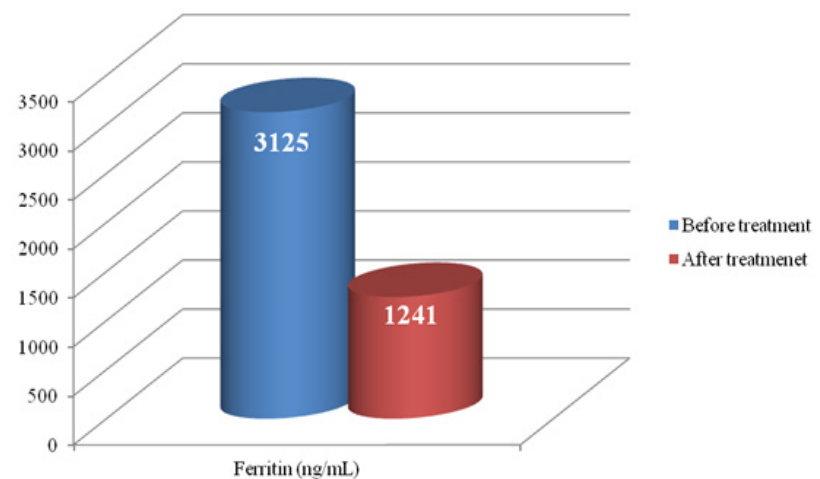

Figure 3 Serum ferritin levels before and after treatment $(n=70)$.

Table 3 Clinical feature of patients $(n=70)$

\begin{tabular}{ll}
\hline Clinical feature & Frequency \\
\hline Fatigue & $59(84.28 \%)$ \\
Weakness & $63(90 \%)$ \\
Pale or yellowish skin & $56(80 \%)$ \\
Facial bone deformities & $5 \mathrm{I}(72.85 \%)$ \\
Slow growth & $44(62.50 \%)$ \\
Abdominal swelling & $43(61.42 \%)$ \\
Dark urine & II $(15.71 \%)$ \\
\hline
\end{tabular}

Table 4 Transfusion Dependency $(\mathrm{n}=70)$

\begin{tabular}{ll}
\hline Transfusion number & Number/Percentage of patients \\
\hline$<5$ times & $4(5.71 \%)$ \\
$5-10$ times & $23(32.85 \%)$ \\
II-20 times & $17(24.28 \%)$ \\
$21-30$ times & $20(28.57 \%)$ \\
$>30$ times & $6(8.57 \%)$
\end{tabular}

\section{Discussion}

Thalassemia is a group of hereditary haemolytic anaemia caused by disruption in the production of haemoglobin chains. Various treatment options are available but the overall compliance, standardization and compliance is poor, due to which many complications develop in patients with thalassemia. ${ }^{9,10}$ Thalidomide is not commonly used in the patients with thalassemia as its role is not fully understood. In our study we evaluated the role of thalidomide to see its effect on haemoglobin and serum ferritin levels. It was found that mean haemoglobin levels was increased after treatment with thalidomide, while serum ferritin levels significantly decreases after treating with thalidomide. It is strongly suggestive of effect of thalidomide on $\mathrm{HbF}$ and also reduction in iron deposition.

Few studies are in favour of these findings. Fozza et al. ${ }^{11}$ presented 2 cases of non-transfusion dependant thalassemia. HbF was significantly raised in these patients after treatment with low-dose thalidomide. ${ }^{11}$ Ali et al. ${ }^{12}$ performed a study in 2016 . He treated patients of $\beta$-thalassemia major with thalidomide and sodium butyrate. He strongly suggested that thalidomide was more efficient than sodium 
butyrate in expression of GATA-1 and EKLF genes, which efficiently induced the HbF levels in these patients. ${ }^{12}$ Ramanan et al. ${ }^{7}$ postulated the same evidence by treating patients with thalidomide. He proved that thalidomide significantly reduced ferritin levels in patients with $\beta$-thalassemia major. ${ }^{7}$ Masera et al. ${ }^{13}$ presented a case of patients with $\beta$-thalassemia major who was resistant to conventional therapy. Thalidomide proved the positive response by inducing $\mathrm{HbF}$ levels in the patient. ${ }^{13}$

Various studies proved to be in favour of our study by showing similar results.

\section{Conclusion}

Thalidomide showed strongly positive results in patients with $\beta$-thalassemia major. Although our study was performed on fewer number of patients so more studies on large populations should be carried out to see strong findings and evidences. Our study did not evaluate the optimal transfusion interval in these patients as there was poor compliance and uneven follow-up of patients at the time of transfusion. Status of splenectomy was not included in this study, so further evaluation is needed in these patients on other parameters as well.

\section{Acknowledgements}

None.

\section{Conflict of interest}

Authors declare that there is no conflict of interest.

\section{References}

1. Kaveh Tari, Pooya Valizadeh Ardalan, Mahnoosh Abbaszadehdibavar et al. Thalassemia an update: molecular basis, clinical features and treatment. Int J BioMed Public Heal. 2018;1(1):48-58.

2. Fibach E, Rachmilewitz EA. Pathophysiology and treatment of patients with beta-thalassemia-an update. F1000Res. 2017;6:2156.
3. Nihar Ranjan Sarker, Ashis Kumar Ghosh, Santosh Kumar Saha, et al. Recent advances in the management of Thalassaemia : A Review Update. J Shaheed Suhrawardy Med Coll. 2014;6(1):31-7.

4. Mettananda S, Gibbons RJ, Higgs DR. $\alpha$-Globin as a molecular target in the treatment of $\beta$-thalassemia. Blood. 2015;125(24):3694-3701.

5. Rund D, Rachmilewitz E. New trends in the treatment of betathalassemia. Crit Rev Oncol Hematol. 2000;33(2):105-118.

6. Dharmesh Chandra Sharma, Anita Arya, Purnima Kishor, et al. Overview on Thalassemias: A Review Article. Med Res Chron. 2017;4(3):325-337.

7. Ramanan V, Kelkar K. Role of Thalidomide in Treatment of Beta Thalassemia. J Blood Disord Med. 2017;3(1):8-10.

8. $\mathrm{Ng} \mathrm{NY}$, Ko CH. Natural Remedies for the Treatment of BetaThalassemia and Sickle Cell Anemia-Current Status and Perspectives in Fetal Hemoglobin Reactivation. Int Sch Res Notices. 2014;2014:123257.

9. Cappellini MD, Porter JB, Viprakasit V, et al. A paradigm shift on betathalassaemia treatment: How will we manage this old disease with new therapies? Blood Rev. 2018;32(4):300-311.

10. De Dreuzy E, Bhukhai K, Leboulch P, et al. Current and future alternative therapies for beta - thalassemia major. Biomed $\mathrm{J}$. 2016;39(1):24-38.

11. Fozza C, Pardini S, Giannico DB, et al. Dramatic erythroid response to low-dose thalidomide in two patients with transfusion independent thalassemia and severe post-transfusional alloimmune hemolysis. Am J Hematol. 2015;90(7):E141.

12. Jalali Far MA, Dehghani Fard A, Hajizamani S, et al. Thalidomide is more efficient than sodium butyrate in enhancing GATA-1 and EKLF gene expression in erythroid progenitors derived from HSCs with $\beta$-globin gene mutation. Int J Hematol Oncol Stem Cell Res. 2016;10(1):37-41.

13. Masera N, Tavecchia L, Capra M, et al. Optimal response to thalidomide in a patient with thalassaemia major resistant to conventional therapy Case description. Blood Transfus. 2010;8(1):63-65. 